Hydrology and Earth System Sciences, 8(4), 673-685 (2004) C EGU

\title{
Wetland nutrient removal: a review of the evidence
}

\author{
J. Fisher and M.C. Acreman \\ Centre for Ecology and Hydrology, Wallingford, OX10 8BB, UK \\ Email for corresponding author: jafi@ceh.ac.uk
}

\begin{abstract}
Data from 57 wetlands from around the world have been collated to investigate whether wetlands affect the nutrient loading of waters draining through them; the majority of wetlands reduced nutrient loading and there was little difference in the proportion of wetlands that reduced $\mathrm{N}$ to those that reduced $\mathrm{P}$ loading. However, some wetlands increased nutrient loadings by increasing the loading of soluble $\mathrm{N}$ and $\mathrm{P}$ species thus potentially driving aquatic eutrophication. Studies conducted over a period of a year or more, or that involved frequent sampling during high flow events, were more likely to indicate that the wetland increased nutrient loadings. Swamps and marshes differed from riparian zones in their nutrient function characteristics by being slightly more effective at nutrient reduction than riparian zones. The attributes that enable wetlands to be effective in reducing $\mathrm{N}$ and $\mathrm{P}$ loadings need consideration when constructing or managing wetlands to reduce nutrient loadings. Their wise use will be an important strategy for meeting the Water Framework Directive requirements for many water bodies.
\end{abstract}

Keywords: wetlands, nutrient functioning, nitrogen, phosphorus, riparian, swamps, marshes, eutrophication

\section{Introduction}

The conservation, restoration and creation of wetlands around the globe are often justified in terms of the beneficial functions and values they contribute to the wider environment. Benefits of such schemes include conserving wildlife, maintenance of biodiversity, provision of products (such as fish, reeds, timber, fuelwood and medicines), microclimate stabilisation, flood control, groundwater recharge and water quality improvements (CEC, 1995; Dugan, 1990; Maltby, 1990; Hogen et al., 1992). Wetlands are often cited as being effective at reducing nutrient loadings, acting as "the kidneys of the catchment" (Mitchell, 1994, Mitch and Gosselink, 1986) thereby reducing eutrophication in adjacent water bodies. This has led to wetlands being managed or constructed as buffers or for treatment of domestic or industrial waste (Allinson et al., 2000). Such water management policy has been built on the assumption that wetlands perform specific hydrological and water quality functions.

Bullock and Acreman (2003) reviewed the water quantity functions of wetlands and found that some research results concluded counter functions. Hence, it is important to review the effectiveness of wetlands in improving water quality, particularly because of a number of concerns regarding the use of wetlands to reduce nutrient loadings. For example, it has been found that wetlands used to reduce nutrient loadings may become degraded (Osborne and Totome, 1994; Chague-Goff et al., 1999) and incomplete denitrification may release the greenhouse and ozone depleting gas, nitrous oxide (Machefert et al., 2002). These issues are particularly topical given the use of wetlands as an important element in river basin management strategies, for instance, within the River Danube and River Tisza catchments.

This review assesses whether or not natural wetlands reduce nutrient loadings to water bodies. Factors thought to influence wetland functioning and the effectiveness of wetlands as nutrient removal mechanisms are examined. By reviewing studies of natural wetlands it is hoped to identify the key processes which govern nitrogen $(\mathrm{N})$ and phosphorus (P) reduction, thus enabling wetlands to be constructed and managed to maximise their nutrient reduction potential. 


\section{How can wetlands change nutrient loads?}

Wetlands reduce nutrients by encouraging sedimentation (Karr and Schlosser, 1978; Johnston et al., 1984), sorbing nutrients to sediments (see Khalid et al., 1977), taking up nutrients in plant biomass (Lee et al., 1975) and enhancing denitrification (Lowrance et al., 1984). While the evidence for this arises from a number of separate studies, some studies show that wetlands can be ineffective at reducing nutrient loadings, or might even increase nutrient loadings. For example, in many wetlands the retention of soluble $\mathrm{P}$ is much less efficient than the retention of particulate $\mathrm{P}$ (UusiKamppa et al., 1997). Also waterlogged sediments are known to release P into overlying waters (Mortimer, 1941); it is then more likely to be exported from the wetland. N, on the other hand, may be removed from the wetland completely via denitrification, which occurs under anaerobic conditions, and are more likely to be found in water-logged sediments (Jordan et al., 1993). However, the microbial activity which controls denitrification can be reduced at low soil temperatures and pH (Ambus and Christensen, 1993; Machefert et al., 2002). Denitrification rates can also be limited by carbon availability and, in this way, vegetation can influence denitrification rates indirectly (Broadbent and Clark, 1965). Vegetation may also influence nitrification and denitrification by influencing the oxygen concentration of the wetland substrate within the rhizosphere (Armstrong, 1964) or by providing bacteria which can fix $\mathrm{N}$ in root nodules, such as in the wetland tree Alnus spp. (Hurd et al., 2001). There is evidence that $\mathrm{N}$ removal efficiency is not affected by the length of time the wetland has received $\mathrm{N}$ pollution while, in contrast, the ability of a wetland to remove $\mathrm{P}$ is known to decline with time (Nichols, 1983; Richardson, 1985). As a result, wetlands have been associated primarily with a reduction in $\mathrm{N}$ loading, rather than functioning to reduce $\mathrm{P}$ loading to water bodies.

This combination of physical, chemical and biological processes means wetlands will be important in preserving and enhancing the status of water bodies under the Water Framework Directive (2000/60/EU). Where the wetlands are also to be protected and enhanced under this legislation, it will be a careful balancing act to maximise their water purification potential without causing wetland degradation.

\section{Collation of evidence}

A literature review gathered evidence to show natural wetlands increasing, decreasing or having no net effect on nutrient loadings. The review examined over 57 wetlands from 60 publications or reports from 16 countries (see Fig.
1). The evidence was divided primarily into

(1) Those that resulted in overall reduction of nutrient loading,

(2) Those which caused an increase in nutrient loading, and

(3) Those that appeared to cause neither net retention nor release during the period of monitoring.

Information has been collated on the percentage change in the nutrient loading which occurred with passage through the wetland, wetland type, annual nutrient loading, nutrient concentration, predominant vegetation species and country of location. The monitoring frequency, species of $\mathrm{N}$ and $\mathrm{P}$ analysed, and duration of each study was noted. This information is held on a database established at the Centre for Ecology and Hydrology (CEH), Wallingford, UK. The studies consulted used broadly similar methods by which the nutrient concentrations in in-flowing waters and of outflowing waters were analysed periodically over time. Frequency of sampling varied and often automatic samplers were used to allow samples to be taken several times a day or to allow increased sampling frequency with increased discharge (see, for example, Raisin and Mitchell, 1995; Jordan et al., 2003). Studies that did not conform to this pattern, such as those that analysed only $\mathrm{N}$ or $\mathrm{P}$ removal by single chemical, biological or physical mechanisms or which predicted $\mathrm{N}$ and $\mathrm{P}$ reductions from model simulations, were not included.

Wetlands showing nutrient retention are defined as those where the nutrient loading of waters draining from the wetlands was less than the nutrient loading of waters entering the wetlands. Nutrient loads have been examined in surface and/or ground waters.

To achieve consistency, the wetlands studied were divided
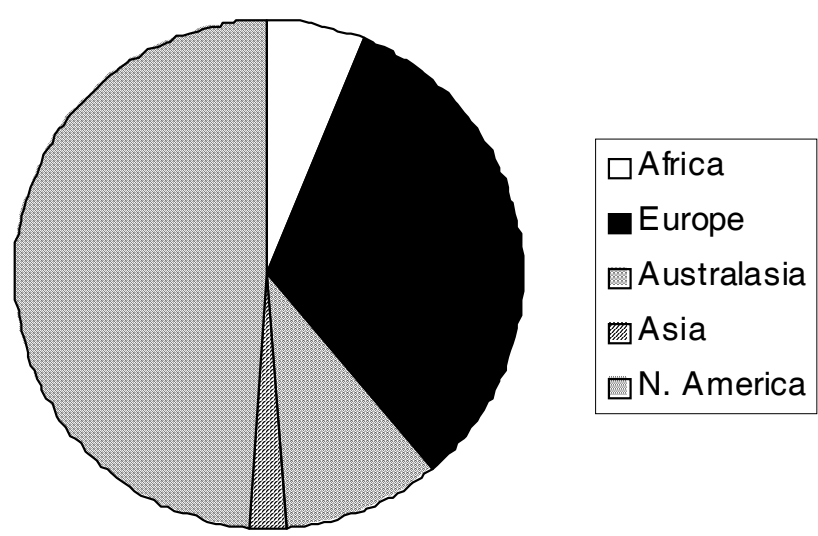

Fig. 1. The proportion of countries from which wetland studies have been reviewed. 
into wetland types using the broad classifications listed in the Ramsar Convention (Hogan et al., 1992). This classification involved examining the description of each wetland, especially the soil, vegetation and basic hydrology in each report, and assigning the wetland to the most appropriate class. Table 1 summarises the studies used, classified into the three functional groups. Individual references appear more than once where more than one wetland has been studied within that reference, and in different functional categories where the monitored species of $\mathrm{N}$ and $\mathrm{P}$ respond differently to passage through the wetland.

The study aimed to answer the following research questions:

(1) Is $\mathrm{N}$ or $\mathrm{P}$ retained within natural wetlands?

(2) Which type of wetland is the most effective at removing $\mathrm{N}$, and which at removing $\mathrm{P}$ ?

(3) What are the main influences on changes to nutrient loading and what lessons can be learnt from these?

\section{Results}

\section{Is $N$ or P retained within natural wetlands?}

Table 1 shows that the majority of wetlands studied (80\%) exhibited nutrient retention (Table 2). When the fate of all $\mathrm{N}$ and $\mathrm{P}$ species were examined, a slightly smaller proportion of wetlands exhibited $\mathrm{N}$ retention $(4 \%)$ than $\mathrm{P}$ retention. Increases in $\mathrm{N}$ loading were also reported from a greater proportion of wetlands (3\%) than increased P loading (Table 2 ). Relatively few studies found no change in nutrient concentration. When the $\mathrm{N}$ loading was reduced, the reduction was, on average, greater $(9 \%)$ than that of $\mathrm{P}$. This, however, was not statistically different because of the high variability between wetlands. Some studies reported 100\% reduction in $\mathrm{N}$ and $\mathrm{P}$ loading while other studies reported $\mathrm{N}$ loading reductions of only $1 \%$ and $\mathrm{P}$ loading reductions of $5 \%$ in some wetlands.

Where $\mathrm{N}$ and $\mathrm{P}$ concentrations were increased, these increases were two- to three-fold and variability between wetlands was extremely high (Table 2). Where increases in $\mathrm{N}$ concentration have been recorded, they have occurred generally as increases in the soluble species, rather than as total or particulate $\mathrm{N}$ (Table 1).

Which type of wetland is the most effective at removing $N$, and which at removing $P$ ?

Marshes or swamps and riparian zones, including riparian buffer strips, were the most commonly studied wetlands in the literature examined. The proportion of each that increased or decreased nutrient loadings was compared by examining data from 20 marshes or swamps and 22 riparian zones (Fig. 2). A greater proportion of riparian zones (10\%) were likely to reduce TN ( total or Kjeldahl N) than swamps and marshes, but a greater percentage $(40 \%)$ of swamps and marshes exhibited overall retention of ammonium-N than did the riparian wetlands.

A slightly greater proportion (7\%) of the riparian wetlands reduced TP loading than did swamps or marshes. But, a greater proportion (37\%) of the riparian wetlands increased loadings of soluble $\mathrm{P}$, and riparian wetlands appear to be more likely to increase soluble P loading than to reduce it (Fig. 2).

What are the main influences on changes to nutrient reduction and what lessons can be learnt from these?

The factors that authors stated as being important in determining the nutrient retention are shown in Fig. 3. Highly interrelated factors have been grouped together. Oxygen concentration within the sediments was the factor most commonly quoted as being of importance to the retention of both $\mathrm{N}$ and $\mathrm{P}$ (Fig. 3). In the retention of $\mathrm{N}$, the oxygen content of the sediment was referred to, along with related measures of redox and the degree of water-logging. In the retention of $\mathrm{P}$, the oxygen content of the sediment was described as of being of importance in relation to the binding capacity of $\mathrm{Fe}$ and $\mathrm{Al}$ with $\mathrm{P}$. The most frequently quoted significant influencing factors (after oxygen concentration) were hydraulic retention time, hydraulic loading and vegetation processes. Vegetation processes include direct influences, such as nutrient uptake through shoots and nutrient release processes during vegetation decomposition, as well as indirect influences such as vegetation effects on sediment composition (e.g. carbon content). Flow volume, retention time and vegetation processes were stated as being of importance in the retention of both $\mathrm{N}$ and $\mathrm{P}$ within wetlands. In the retention of $\mathrm{N}$, fluctuating water height was important in relation to the influence this has on nitrification-denitrification processes, while the duration of nutrient loading was the next most often quoted variable of importance in the retention of $\mathrm{P}$ (Fig. 3).

Figures $4 \mathrm{a}$ and $\mathrm{b}$ show the relationship between total $\mathrm{N}$ and $\mathrm{P}$ loading, respectively, and the nutrient reduction abilities of wetlands. It was not possible to investigate the relationship between wetland oxygen status or hydraulic loading and nutrient removal because many of the studies did not provide redox values or information on the inflowing water discharge. Figures $4 \mathrm{a}$ and $\mathrm{b}$ show that the wetland reduction capabilities are more strongly negatively correlated to an increase in $\mathrm{N}(\mathrm{p}<0.05)$ than to $\mathrm{P}(\mathrm{p}=$ not significant) loading. $\mathrm{N}$ loading explained $35 \%$ of the 
Table 1. Summary of references studied showing wetland name, wetland type and country of location. References are split into those showing an increase in nutrient loading, decrease in nutrient loading and those showing no change. $\mathrm{N}=$ several $\mathrm{N}$ species, $\mathrm{P}=$ several $\mathrm{P}$ species, $\mathrm{TP}=$ total phosphorus, $\mathrm{TN}=$ total or Kjeldahl $\mathrm{N}, \mathrm{sol}=$ soluble $\mathrm{N}$ or $\mathrm{P}, \mathrm{SRP}=$ soluble reactive $\mathrm{P}, \mathrm{TPN}=$ total particulate $\mathrm{N}$, $\mathrm{PN}=$ particulate $\mathrm{N}, \mathrm{P}_{4}=$ orthophosphate, $\mathrm{NO}_{3}=$ nitrate, $\mathrm{NO}_{2}=$ nitrite and $\mathrm{NH}_{4}=$ ammonium, including ammonium- $\mathrm{N}$.

\begin{tabular}{|c|c|c|c|c|c|}
\hline Author(s) & Date & $N$ or $P$ & Wetland name & Wetland type & Country \\
\hline \multicolumn{6}{|l|}{ Nutrient Retention } \\
\hline Raisin and Mitchell & 1995 & TPN & Humphrey's wetland & marsh/swamp & Australia \\
\hline Raisin and Mitchell & 1995 & $\mathrm{TP}$ & Reid's wetland & $\mathrm{marsh} / \mathrm{swamp}$ & Australia \\
\hline Jacobs and Gilliam & 1985 & $\mathrm{NO}_{3}$ & unknown & riparian & USA \\
\hline Cooper and Gilliam & 1987 & $\mathrm{P}$ & unknown & riparian & USA \\
\hline Lowrance et al.. & 1984 & $\mathrm{NO}_{3}$ & unknown & riparian & USA \\
\hline Cooke & 1994 & $\mathrm{P}, \mathrm{NO}_{3}$ & unknown & marsh/swamp & $\mathrm{NZ}$ \\
\hline Bugenyi & 1993 & $\mathrm{~N}, \mathrm{P}$ & unknown & riparian & Uganda \\
\hline Patruno and Russell & 1994 & $\mathrm{~N}, \mathrm{P}$ & Yamba wetland & $\mathrm{marsh} / \mathrm{swamp}$ & Australia \\
\hline $\begin{array}{l}\text { Baker and Maltby } \\
\text { UK }\end{array}$ & 1995 & $\mathrm{NO}_{3}, \mathrm{NO}_{4}$ & \multicolumn{2}{|c|}{ Kismeldon Meadows and Bradford Mill } & riparian \\
\hline Peterjohn and Correll & 1984 & sol P & Rhode River drainage basin & riparian & USA \\
\hline Jordan et al.. & 1993 & $\mathrm{NO}_{3}, \mathrm{TP}$ & Chester River catchment & floodplain & USA \\
\hline Gehrels and Mulamootth & 1989 & $\mathrm{TP}$ & unknown & $\mathrm{marsh} / \mathrm{swamp}$ & USA \\
\hline Burt et al.. & 1998 & $\mathrm{NO}_{3}$ & R.Leach floodplain & floodplain & UK \\
\hline Haycock and Burt & 1993 & $\mathrm{NO}_{3}$ & R.Leach floodplain & floodplain & UK \\
\hline Cooper & 1994 & $\mathrm{NO}_{3}$ & unknown & swamp & $\mathrm{NZ}$ \\
\hline Prior & 1998 & $\mathrm{~N}, \mathrm{P}$ & R. Lambourn floodplain & floodplain & UK \\
\hline Haycock and Pinay & 1993 & $\mathrm{NO}_{3}$ & R.Leach floodplain & riparian & UK \\
\hline Chauvelon & 1998 & $\mathrm{~N}, \mathrm{P}$ & Rhone river delta & riverine delta & France \\
\hline Maltby et al.. & 1995 & $\mathrm{~N}$ & Floodplains in Devon & floodplain & UK \\
\hline Osborne and Totome & 1994 & $\mathrm{TP}, \mathrm{SRP}, \mathrm{NH}_{4}$ & Waigani & $\mathrm{marsh} / \mathrm{swamp}$ & Papua N.Guinea \\
\hline Cooper & 1990 & $\mathrm{NO}_{3}$ & Scotsman Valley, NZ & riparian & $\mathrm{NZ}$ \\
\hline Lindkvist and Hakansson & 1993 & $\mathrm{TP}$ & unknown & unknown & Sweden \\
\hline Lindkvist & 1992 & $\mathrm{TP}$ & unknown & unknown & Sweden \\
\hline Mander et al.. & 1991 & $\mathrm{TP}$ & unknown & various & Estonia \\
\hline Nunez Delgado et al.. & 1997 & $\mathrm{NO}_{3}$ & unknown & riparian & Spain \\
\hline Mander et al.. & 1997 & $\mathrm{~N}, \mathrm{P}$ & Porijogi River catchment & riparian & Estonia \\
\hline Downes et al.. & 1997 & $\mathrm{NO}_{3}$ & Whangamata Stream & riparian & $\mathrm{NZ}$ \\
\hline Brinson et al.. & 1984 & $\mathrm{~N}, \mathrm{P}$ & Tar River floodplain & riparian & USA \\
\hline Brunet et al.. & 1994 & $\mathrm{PN}$ & Adour River floodplain & floodplain & France \\
\hline Tilton and Kadlec & 1979 & $\mathrm{~N}, \mathrm{P}$ & unknown & fen & USA \\
\hline Burke & 1975 & $\mathrm{~N}, \mathrm{P}$ & unknown & peatland & Ireland \\
\hline Boyt et al.. & 1977 & $\mathrm{P}$ & unknown & $\mathrm{marsh} / \mathrm{swamp}$ & USA \\
\hline Spangler & 1977 & $\mathrm{P}$ & unknown & $\mathrm{marsh} / \mathrm{swamp}$ & USA \\
\hline Yonika and Lowry & 1979 & $\mathrm{~N}$ & unknown & $\mathrm{marsh} / \mathrm{swamp}$ & USA \\
\hline Semkin et al.. & 1976 & $\mathrm{~N}, \mathrm{P}$ & unknown & $\mathrm{marsh} / \mathrm{swamp}$ & USA \\
\hline Semkin et al.. & 1976 & $\mathrm{~N}, \mathrm{P}$ & unknown & marsh/swamp & USA \\
\hline Johnston et al.. & 1984 & $\mathrm{~N}, \mathrm{P}$ & nr White Clay Lake & $\mathrm{marsh} / \mathrm{swamp}$ & USA \\
\hline Johnston et al.. & 1984 & $\mathrm{~N}, \mathrm{P}$ & nr White Clay Lake & riparian & USA \\
\hline Pinay and Decamps & 1988 & $\mathrm{~N}$ & Garonne Valley & riparian & France \\
\hline Jordan et al.. & 2003 & TN, TP & Kent Island & $\mathrm{marsh} / \mathrm{swamp}$ & USA \\
\hline Mwanuzi et al.. & 2003 & $\mathrm{PO}_{4}$ & unknown & riparian & Tanzania \\
\hline Rzepecki & 2002 & sol P & unknown & riparian & Poland \\
\hline Zhang et al.. & 2000 & TN, TP & unknown & $\mathrm{marsh} / \mathrm{swamp}$ & USA \\
\hline Bratli et al.. & 1999 & $\mathrm{~N}, \mathrm{P}$ & unknown & marsh/swamp & Norway \\
\hline Kellog and Bridgeham & 2003 & P04 & unknown & peatland & USA \\
\hline Kansiime and Nalubega & 1999 & $\mathrm{~N}$ & unknown & $\mathrm{marsh} / \mathrm{swamp}$ & Uganda \\
\hline
\end{tabular}




\begin{tabular}{|c|c|c|c|c|c|}
\hline Author(s) & Date & $N$ or $P$ & Wetland name & Wetland type & Country \\
\hline Kansiime and Nalubega & 1999 & $\mathrm{~N}$ & unknown & marsh/swamp & Uganda \\
\hline Chescheir et al.. & 1991 & $\mathrm{TP}, \mathrm{NO}_{3}$ & unknown & riparian & USA \\
\hline Dorge & 1994 & $\mathrm{NO}_{3}$ & Rabis Baek & peatland & Denmark \\
\hline Dorge & 1994 & $\mathrm{NO}_{3}$ & Syvbaek & riparian & Denmark \\
\hline Dorge & 1994 & $\mathrm{NO}_{3}$ & Glumso & marsh/swamp & Denmark \\
\hline Schlosser and Karr & 1981 & $\mathrm{TP}$ & Champaign-Urbana & riparian & USA \\
\hline Hanson et al.. & 1994 & $\mathrm{NO}_{3}$ & nr Kingston & riparian & USA \\
\hline Schwer and Clausen & 1989 & $\mathrm{TP}, \mathrm{TN}$ & nr Charlotte & riparian & USA \\
\hline Daniels and Gilliam & 1996 & $\mathrm{~N}, \mathrm{P}$ & Cecil soil area & riparian & USA \\
\hline \multicolumn{6}{|l|}{ Nutrient AdDition } \\
\hline Cooke & 1994 & $\mathrm{NO}_{3}$ & unknown & & NZ \\
\hline Peterjohn and Correll & 1984 & sol P & unknown & riparian & USA \\
\hline Jordan et al.. & 1993 & $\mathrm{~N}, \mathrm{P}$ & Chester River catchment & floodplain & USA \\
\hline Gehrels and Mulamootth & 1989 & sol P & unknown & marsh/swamp & USA \\
\hline Prior & 1998 & TDN, TDP & R. Lambourne floodplain & floodplain & UK \\
\hline Osborne and Totome & 1994 & $\mathrm{NO}_{2}, \mathrm{NO}_{3}$ & Waigani & marsh/swamp & Papua N.Guinea \\
\hline Downes et al.. & 1997 & $\mathrm{NO}_{3}, \mathrm{SRP}$ & Whangamata Stream & riparian & NZ \\
\hline Clausen et al.. & 1993 & $\mathrm{TN}$ & unknown & riparian & USA \\
\hline Daniels and Gilliam & 1996 & $\mathrm{~N}, \mathrm{P}$ & Georgeville Soil Area & riparian & USA \\
\hline \multicolumn{6}{|c|}{ NO NET NUTRIENT RETENTION/ADDITION } \\
\hline Raisin and Mitchell & 1995 & TPN & Reid's wetland & marsh/swamp & Australia \\
\hline Kadlec & 1985 & $\mathrm{P}$ & unknown & marsh/swamp & USA \\
\hline Elder & 1985 & $\mathrm{~N}$ & Apalachicola River floodplain & floodplain & USA \\
\hline Ontkean et al.. & 2003 & $\mathrm{~N}, \mathrm{P}$ & Hilton Wetland & pond & Canada \\
\hline Daniels and Gilliam & 1996 & TP, PO4 & Georgeville Soil Area & riparian & USA \\
\hline
\end{tabular}

Table 2. Summary of the number and percentage of studies of wetlands which reduced, increased or resulted in no change to $\mathrm{N}$ or $\mathrm{P}$ loading

\begin{tabular}{|c|c|c|c|c|c|c|c|c|}
\hline & \multicolumn{4}{|c|}{ Nitrogen SPECIES } & \multicolumn{4}{|c|}{ PhOSPHORUS SPECIES } \\
\hline & $\begin{array}{l}\text { No. } \\
\text { wetlands }\end{array}$ & $\begin{array}{l}\% \\
\text { wetlands }\end{array}$ & $\begin{array}{l}\text { Mean } \\
\% \text { change }\end{array}$ & $\begin{array}{l}\text { SD of mean } \\
\% \text { change }\end{array}$ & $\begin{array}{l}\text { No. } \\
\text { wetlands }\end{array}$ & $\begin{array}{l}\% \\
\text { wetlands }\end{array}$ & $\begin{array}{l}\text { Mean } \\
\text { \% change }\end{array}$ & $\begin{array}{l}\text { SD of } \\
\% \text { change }\end{array}$ \\
\hline Retention & 43 & 80 & 67 & 27 & 41 & 84 & 58 & 23 \\
\hline Release & 7 & 13 & 351 & 432 & 5 & 10 & 221 & 328 \\
\hline No net change & 4 & 7 & $\mathrm{n} / \mathrm{a}$ & $\mathrm{n} / \mathrm{a}$ & 3 & 6 & $\mathrm{n} / \mathrm{a}$ & $\mathrm{n} / \mathrm{a}$ \\
\hline
\end{tabular}

variation in $\mathrm{N}$ reduction. The relationship between the concentration of $\mathrm{N}$ and $\mathrm{P}$ flowing into the wetland and the percentage of $\mathrm{N}$ and $\mathrm{P}$ loading reduced by the wetlands was also investigated. There was no relationship between inflow $\mathrm{N}$ concentration and nutrient reduction, and the number of studies which cited both inflow $\mathrm{P}$ concentration and percentage nutrient reduction was too few to be statistically significant.

\section{Discussion}

Is $N$ or P more effectively retained within natural wetlands? Evidence from the 57 wetlands examined shows that $80 \%$ of wetlands studied for changes in $\mathrm{N}$ functioning reduced $\mathrm{N}$ loading while $84 \%$ of wetlands studied for P functioning reduced $\mathrm{P}$ loadings in the water flowing through them. Table 2 suggests that a slightly greater proportion of wetlands reduced $\mathrm{P}$ loadings than reduced $\mathrm{N}$ loadings, and a greater proportion of wetlands increased $\mathrm{N}$ than $\mathrm{P}$ loadings (Table 
J. Fisher and M.C. Acreman
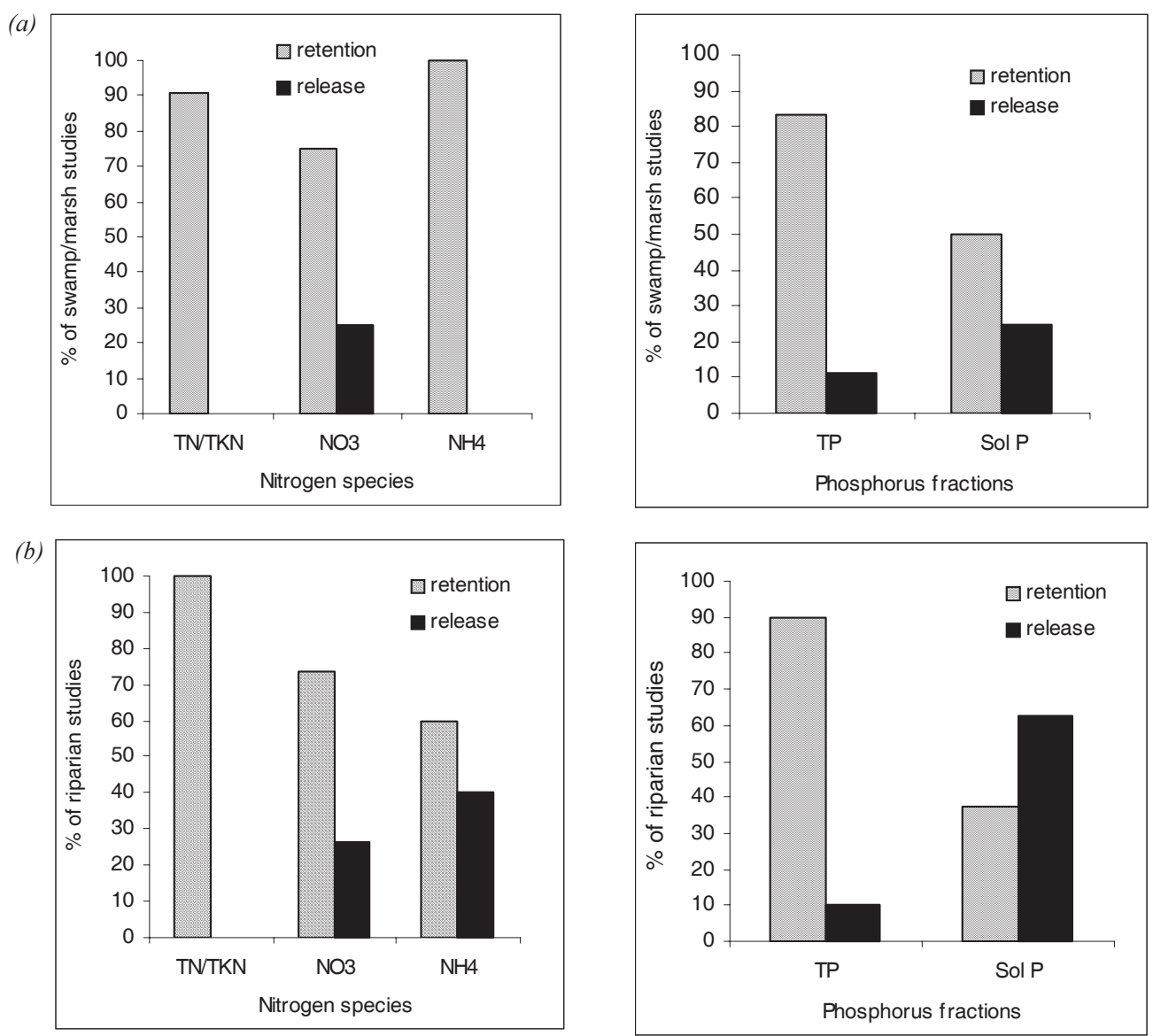

Fig. 2. The percentage of wetlands studied which exhibited nutrient reduction and an increase in $N$ and $P$ loading. (a) swamp/marshes and (b) riparian zones.

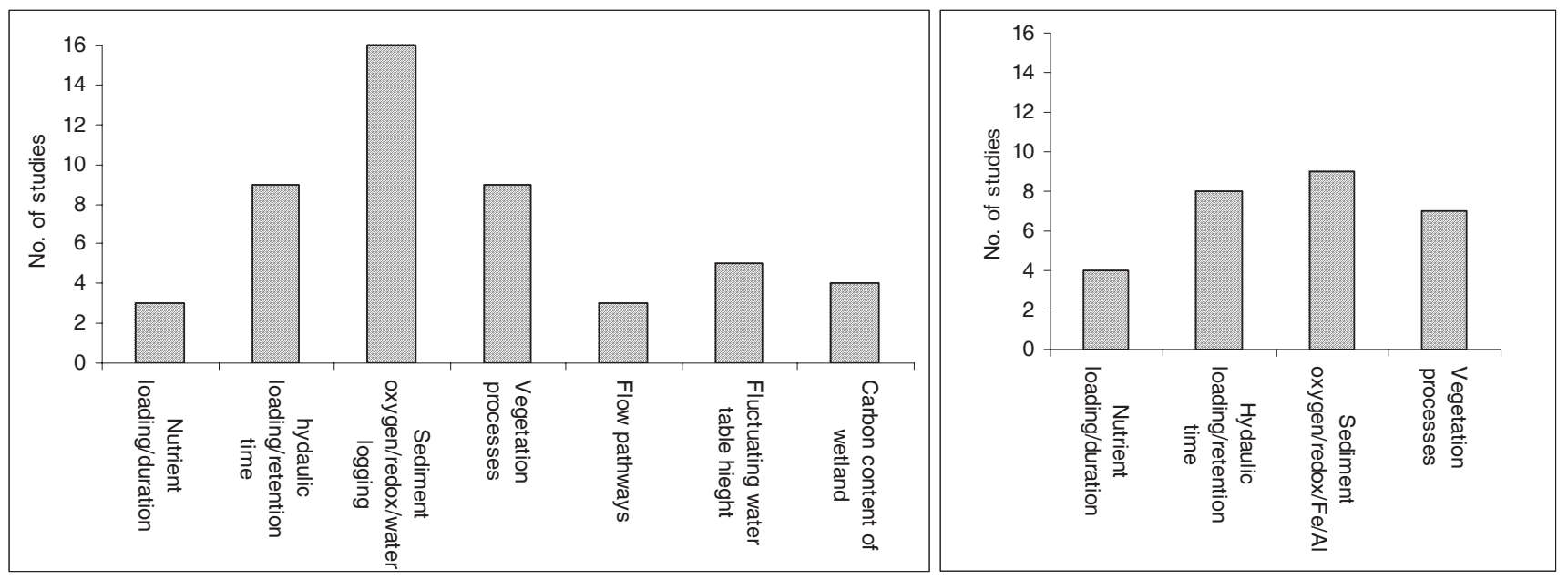

Fig. 3. The factors most commonly quoted as being of importance to the nutrient retention or reduction abilities of (a) swamps and marshes and (b) riparian zones. 

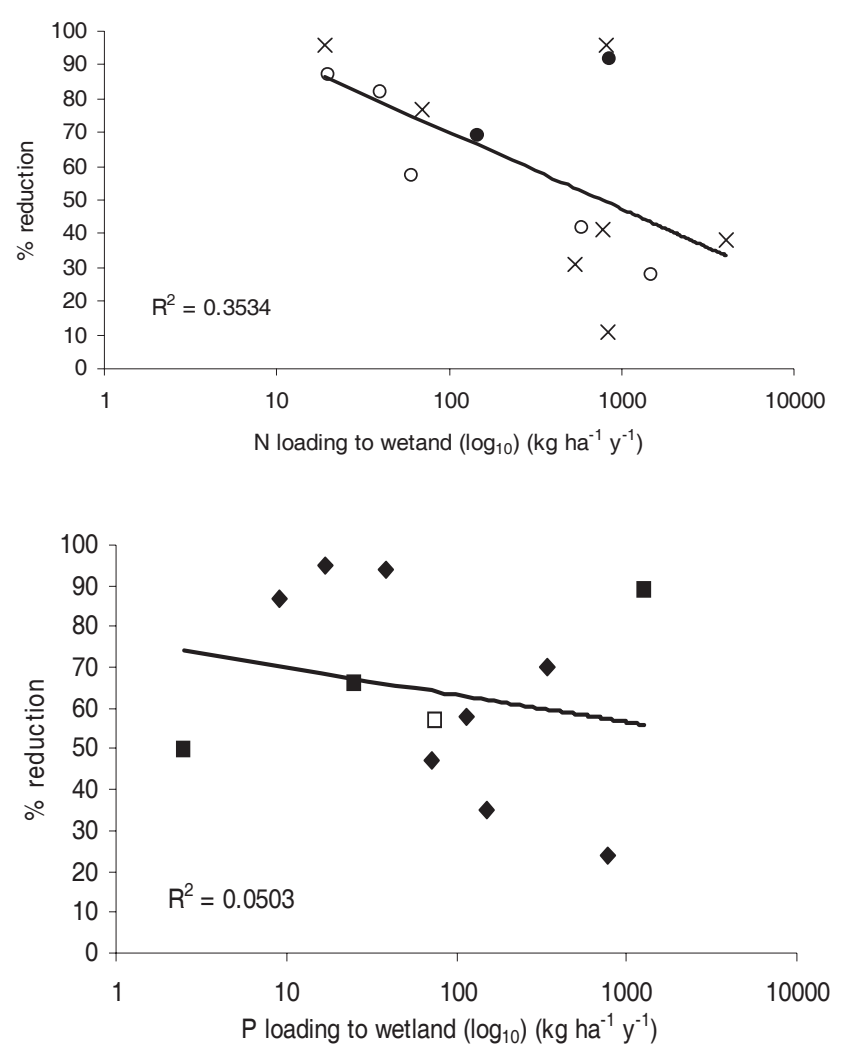

Fig. 4. Relationship between nutrient reduction within wetlands and the amount of a) $N$ loading to wetlands and b) $P$ loading to wetlands reported in a study. $(\bullet=T N, \mathrm{O}=$ nitrate and $\times=$ several $N$ species and b) P loading to wetlands, $\quad \mathbf{\square}=T P, \quad \square=$ orthophosphate and $\downarrow=$ several $P$ species).

2). This is surprising, given that wetlands are generally thought to be more efficient at reducing $\mathrm{N}$ loadings than $\mathrm{P}$ (Nichols, 1983), primarily through denitrification which removes N from the system (Hill and Sanmugadas, 1985; Bowden, 1987). It is likely that because studies of wetland nutrient functioning have tended to focus on $\mathrm{N}$ dynamics more commonly than $\mathrm{P}$ dynamics, more species of $\mathrm{N}$ have been monitored. It is possible, therefore, that losses of $\mathrm{P}$ from some wetlands have been underestimated.

Many studies argue that wetlands reduce $P$ less efficiently than $\mathrm{N}$ as, unlike $\mathrm{N}$ which can be lost to the atmosphere from the wetland via denitrification, $\mathrm{P}$ cannot be lost from the system (Vanek, 1991). However, orthophosphate $\left(\mathrm{PO}_{4}\right)$ and TP were also removed by up to $100 \%$ from water flowing through a peat land (Kellog and Bridgeham, 2003) and a forested riparian area (Chescheir et al., 1991). Due to the temporary nature of the P storage, which is attached to sediment or incorporated into vegetation biomass, it is unlikely that $100 \%$ reduction efficiency could be maintained. Indeed, in the case of the peat land study (Kellog and
Bridgeham, 2003) the experiment was carried out over a period of only 30 days. Some researchers postulate that wetlands 'age' and that after a period of around 50 years wetland nutrient reduction functioning is reduced to below $40 \%$ (Nichols, 1983). The sediment sites to which P can bind become saturated, and $\mathrm{P}$ retention efficiency is reduced (Omernik et al., 1981; Richardson, 1985). Gehrels and Mulamootth (1989) note that the P removal mechanisms are exceeded when the wetland cannot produce soil at a sufficient rate to provide binding sites. Of the studies that recorded over $95 \%$ reduction in $\mathrm{P}$ loading, none were conducted for more than two years and therefore there is very little evidence for the long term ability of wetlands to reduce $\mathrm{P}$ loadings to such a high efficiency.

From the papers reviewed here there is little evidence of the $\mathrm{N}$ reduction efficiency declining with wetland age. Downes et al. (1997) recorded nitrate concentrations regularly over 14 years and still found an average $\mathrm{N}$ reduction efficiency of $97 \%$. Many of the studies which recorded over $90 \% \mathrm{~N}$ reduction appear to have been conducted on a regular weekly or monthly sampling strategy (Baker and Maltby, 1995; Haycock and Pinay, 1993; Pinay and Decamps, 1988) or avoided sampling during high flow events (Cooper, 1990). Those studies that recorded relatively low $\mathrm{N}$ reduction $(<50 \%)$ or highly variable $\mathrm{N}$ reduction were often those that were conducted daily (Cooper, 1994; Jordan et al., 2003) or sampled more regularly during high flows (Raisin and Mitchell, 1995; Brunet et al., 1994; Daniels and Gilliam, 1996), or sampled from many locations within the wetland (Johnston et al., 1984). This is also the case in some of the studies which found relatively low P reduction or variable P reduction (Raisin and Mitchell, 1995; Spangler, 1977; Jordan et al., 2003).

Nichols (1983) reviewed data from nine wetlands which received loadings of waste water and showed that a reduction in nutrient removal functioning occurred in response to an increase in time over which nutrient loading occurred and to an increase in nutrient loading. Despite the combined effects of wetland aging and increased loading, P removal did not fall below about $20 \%$ while the $\mathrm{N}$ reduction capacity fell to below 5\% (Nichols, 1983).

A reduction in nutrient retention ability (Schlosser and Kar, 1981) and transport of soluble $\mathrm{N}$ and $\mathrm{P}$ species from the wetlands is more likely to occur in the autumn, when the vegetation begins to senesce (Raisin and Mitchell, 1995); in temperate environments, this coincides with periods of increased precipitation and flow (Uusi-Kamppa et al., 1997). The increased microbial activity in response to vegetation decay may, however, promote increased denitrification and mineralisation of nutrients within the wetland in autumn. Despite this, outputs of $\mathrm{P}$ generally exceed inputs during 
the autumn (Ross, 1995). Many wetlands appear to reduce nutrient loading but also convert a proportion of the nutrient loading into soluble nutrient species, which are then leached from the wetland, a process which is more likely to occur in the autumn in temperate climates. The variability in increases in nutrient loading between wetlands, however, was extremely high (Table 2).

What type of wetland is the most effective at removing $N$, which at removing $P$ ?

Of the two wetland types examined in more detail (Fig. 2), a greater proportion of riparian areas reduced $\mathrm{TN}$ than did swamps and marshes but none of the swamps and marshes studies reviewed increased ammonium-N loading. Haycock et al. (1997) suggests that $\mathrm{N}$ reduction is greater in wetter environments while $\mathrm{P}$ reduction is greater in drier conditions. Craft and Casey (2000) found P retention to be greater in a floodplain than in nearby depressional wetlands. While denitrification is known to be greater in more waterlogged soils (Jordan et al., 1993), the waterlogging is also likely to produce a more organic soil than more well drained riparian wetlands. Here, the greater carbon availability may also promote denitrification. Cooper (1990) found a disproportionately high $\mathrm{N}$ removal in soils where the organic content was high. The morphology of marsh or swamp areas may also allow them to act predominantly as nutrient sinks. Any soluble nutrients are less easily transported from marshes and swamps into adjacent water bodies as these are characterised by slower water movement than from riparian zones, which, by definition, are adjacent to flowing water.

Riparian areas appear more likely to reduce TP and TN or TKN loading than swamps or marshes (Fig. 2). They were more likely than swamps or marshes to increase the loading of ammonium- $\mathrm{N}$ and soluble $\mathrm{P}$ species. The tendency for riparian areas to increase the soluble $\mathrm{P}$ loading was unexpected, given that riparian wetlands are likely to be better drained, have higher oxygen and redox potentials than water logged marsh or swamps and are generally expected to reduce $P$ effectively (Haycock et al., 1997). The soluble forms of $\mathrm{N}$ and $\mathrm{P}$, in particular, are highly available to aquatic plants and algae and therefore more likely than sediment attached or organic forms of $\mathrm{N}$ and $\mathrm{P}$ to drive eutrophication. A number of studies argue that wetlands in general may increase the concentration of soluble $\mathrm{P}$ species in ground and surface waters (Peterjohn and Correll, 1984; Jordan et al., 1993) but little work has been conducted to investigate if such increases in P loading are associated with particular types of wetland, vegetation or hydrology.

Swamps and marshes tended to reduce TN, TKN and $\mathrm{NH}_{4}$, but some studies found them to increase loadings of $\mathrm{NO}_{3}$.
This increase is unexpected given that under waterlogged and associated low oxygen conditions, it would be expected that $\mathrm{NO}_{3}$ would be reduced to $\mathrm{N}_{2}$ and that $\mathrm{NH}_{4}$ would be more likely to accumulate in the wetland (Ross, 1995). The accumulation and transport of $\mathrm{NO}_{3}$ may occur as a result of enhanced nitrification (Hill and Shackleton, 1989) from the oxygenation zones within the rhizopshere (Armstrong, 1964). An increase in $\mathrm{N}$ loading may also occur in some marshes and swamps where $\mathrm{N}$-fixing Cyanobacteria, or species supporting symbiotic N-fixing bacteria occur e.g. Alnus sp. (Horne, 1971; Schindler, 1977).

Only a small number of the studies looked at nutrient loadings from peat lands or bogs, mangrove swamps or fens, and the majority were conducted in Europe or North America (Fig. 1). There is, therefore, a paucity of information on the effectiveness of wetlands for the retention of nutrients in tropical and semi-tropical regions. Of the wetlands studied in tropical and subtropical regions, most showed overall nutrient retention (Table 1) and, therefore, there is no evidence that these wetlands are any less effective in reducing nutrient loading than those at higher latitudes. This would be expected, given that the chemical transformation processes that are important to nutrient reduction are likely to occur at a greater rate at higher temperatures and not be inhibited by an annual dormant season as in temperate climates.

Information on vegetation and soil properties varied in type and quantity, depending on the focus of the study. This made it difficult to study the relationship between different vegetation covers or different soil types and efficiency of $\mathrm{N}$ or $\mathrm{P}$ reduction.

\section{What lessons can be learned from this assessment of natural wetlands nutrient functioning?}

This assessment of the literature provides important lessons for the management of natural wetlands and for the construction of wetlands in order to maximise their nutrient removal or reduction potential. Increasingly, wetlands, either natural or man-made, are being used to improve the water quality of road run-off, sewage or agricultural run-off. The literature reviewed shows that, on the whole, wetlands reduce $\mathrm{N}$ and $\mathrm{P}$ loadings, but this depends primarily on:

- the degree of water logging;

- the rate of nutrient loading which is at least as significant in determining $\mathrm{N}$ reduction as $\mathrm{P}$ reduction;

- the duration of nutrient loading; this is important in determining $\mathrm{P}$ reduction.

Most significantly, this review suggests that efficient $\mathrm{N}$ and $\mathrm{P}$ removal require differing types of wetland for each. To 
maximise P removal, the wetland substrate should not be reducing, in contrast to the conditions required to maximise denitrification. This will allow $\mathrm{P}$ binding to $\mathrm{Fe}$ and $\mathrm{Al}$ under aerobic conditions and may minimise sediment P-release (Mortimer, 1941; Jensen et al., 1992). Rzepecki (2002) and Vanek (1991) noted increased soluble P transport from wetlands when reducing or water logging conditions prevailed. In contrast, many of the studies reviewed noted that $\mathrm{N}$ loss was maximised by fluctuating water tables (Patrick and Wyatt, 1964) or by a close juxtaposition of aerobic and anaerobic zones within the sediment (Koch et al., 1992).

Hydraulic loading and retention times are significant in determining sedimentation rates and whether nutrients are likely to be flushed from the wetland, the contact time between the nutrient load and the wetland sediment and vegetation (Richardson, 1985; Uusi-Kamppa et al., 1997). Hill (1997) and Mander et al. (1991) have shown that denitrification and sediment P-retention are dependent on water residence times.

The importance of the amount of total nutrient loading to the effectiveness of nutrient reduction was noted in a minority of studies, but was regarded as being of particular significance to a reduction of $\mathrm{P}$ loading (Fig. 3). This contrasts with the results from this collection of studies which show wetland $\mathrm{N}$ reduction to be more strongly negatively correlated to $\mathrm{N}$ loading than $\mathrm{P}$ removal is to $\mathrm{P}$ loading (Fig. 4a and b). Nichols (1983) showed that the percentage of nutrient removal was inversely related to loading and to the number of years the wetland had received anthropogenic nutrient loading. Nichols (1983) found that $\mathrm{P}$ removal did not fall below about $20 \%$ of the original loading, while $\mathrm{N}$ reduction fell to below $5 \%$. This agrees well with the results in Fig. 4 which show $\mathrm{N}$ reduction to decline more sharply than wetland $\mathrm{P}$ reduction with an increase in loading. The phenomenon of wetland 'ageing' has also been noted in wetlands that have received nutrient pollution in studies by Dillaha et al. (1988) and by Patruno and Russell, 1994). Nichols (1983) argues that $\mathrm{N}$ removal efficiency will not decline with age in natural wetlands because their naturally high carbon content will allow the continuation of denitrification (Nichols, 1983). This review has been concerned only with natural wetlands which are likely to have a high $\mathrm{C}$ content but $\mathrm{N}$ reduction ability still appears to be reduced with increased loading (Fig. 4). The importance of carbon on denitrification rates has been argued by Hill and Sanmugadas (1985) although Ambus and Christensen (1993) state that soil carbon is important only in dry soils to aid the development of anaerobic conditions, but unimportant in waterlogged situations.

Reduced water purification capacity has been noted in several constructed wetlands either as a result of overloading (Shutes, 2001) or ageing, which has been found to occur after just one year of use in experimental wastewater treatment mesocosms (Hench et al., 2003). Whilst lower nutrient removal performance is generally associated with increased $\mathrm{P}$ loading, this study shows that $\mathrm{N}$ reduction functioning may be at least as sensitive to increased loading.

While vegetation was seen as being significant in controlling both $\mathrm{N}$ and $\mathrm{P}$ loading (Fig. 3), the effect of vegetation on wetland functioning is multi-faceted. It is generally thought that direct nutrient reduction by plant uptake in wetlands is relatively unimportant in comparison with sediment and chemical transformation processes (Hammer, 1992). Johnston et al. (1984) argue that nutrient removal by sediment may be more long term than uptake by plants which return nutrients as litter, a form that is more vulnerable to leaching and erosion. This can be reduced by plant harvesting before senescence, though it is important not to disturb the sediment and enhance erosion (Merritt, 1994). The organic matter shed by the vegetation may also be important in determining the sediment composition and its ability to reduce nutrient loading (Merritt, 1994). Vegetation is also important in encouraging sedimentation (Uusi-Kamppa et al., 1997), providing a carbon source for denitrification (Haycock and Burt, 1993) and controlling sediment oxygen and water content via respiration, transpiration and influencing humic content. A number of wetland species and aquatic macrophytes within wetlands can stimulate denitrification and nitrification (Hill, 1997), but can enrich the $\mathrm{P}$ content of the water column during senescence (Barko and Smart, 1980; Carpenter, 1980) and enhance P release from sediments (Stephen et al., 1997). Despite this, a smaller proportion of the swamps and marshes increased $\mathrm{P}$ loading than did riparian areas.

If wetlands are to be managed or constructed to maximise nutrient removal or reduction, a monitoring regime may be required to assess effectiveness and intervene where necessary. The review of literature shows that the classification of a wetland as predominantly increasing or decreasing nutrients appeared, in part, to depend on the duration and frequency of sampling, and for which nutrient species the samples were analysed. Wetzel (2001) notes that wetland nutrient retention efficiency varies diurnally, seasonally and spatially and, therefore, sampling strategy should be designed to take account of this if a more accurate indication of nutrient functioning is to be achieved.

\section{OTHER CONSIDERATIONS}

During the search for evidence of the effect of natural wetlands on nutrient loadings, very little information was 
found for tropical and semi-tropical regions; studies from South America were especially lacking (Fig.1). Also, there were relatively few studies on bogs and fens, with most studies being carried out in riparian buffer zones, swamp or marsh areas and floodplains.

This paper has considered only natural wetlands. It has focused on major wetland type, and retention of $\mathrm{N}$ and $\mathrm{P}$ as these drive aquatic eutrophication, and it has dealt with the importance of various environmental factors in determining nutrient function. Brinson et al. (1984) stressed the importance of the shape and size of the wetland and Fleischer et al. (1997) showed that $\mathrm{N}$ and $\mathrm{P}$ retention were highly correlated to both wetland size and nutrient loading. There was insufficient consistency in the reporting of wetland size and hydraulic loading to consider the influence of these variables on wetland functioning in more detail. There were also many variations in the descriptions of the hydrology and, therefore, the effectiveness of the different wetlands could not be discussed in terms of the degree of loading from surface and groundwater sources. This is a particularly important variable given that the majority of chemical and biological factors which determine nutrient retention and removal are largely confined to the upper sediment layers.

When considering the most effective hydrological, sediment and possibly vegetation conditions for maximum $\mathrm{N}$ or $\mathrm{P}$ loading reduction, it is important to consider the condition of the receiving water body. For instance, the literature review shows that a greater proportion of riparian zones are likely to increase the loading of soluble P than swamps or marshes. This would be of concern when the wetland is adjacent to P-limited water bodies or water bodies with low flushing rates, e.g. many lowland UK lakes, where $\mathrm{P}$ is likely to be retained (James et al., 2003). This would also be of importance when the receiving water body is Plimited, while N-reduction will be especially important in wetlands adjacent to N-limited water bodies.

Even though a number of wetland studies found an increase in nutrient loading, especially of soluble nutrient species, much of this increase is likely to occur in the autumn when the wetland plants shed litter or die back and when higher flows and erosion occur. This may not be particularly detrimental to aquatic ecology since nutrient uptake by the receiving aquatic plants and algae will be relatively small during autumn and winter, and providing the nutrients are flushed from the system. The flushing and dilution of these nutrient outputs are also likely to be relatively great at this time of year as river flows are high.

The effects of nutrient loading on the flora and fauna of wetlands have not been considered. While wetlands may act to reduce the eutrophication of adjacent ecosystems, they may become eutrophic themselves. Increased weed invasion
(Chague-Goff et al., 1999) and reduced plant diversity (Osborne and Totome, 1994) have been reported. There has also been a paucity of studies to assess the effectiveness of long term nutrient reductions and the ecological effects on the wetland of receiving such nutrient loadings. This is an important consideration if the small numbers of wetlands that are still retained in the UK and Europe are expected to reduce and retain the vast quantities of nutrients that flow through them from our agricultural catchments (Haycock et al., 1997).

The Water Framework Directive (2000/60/EU) states that wetlands which are "directly depending on...aquatic ecosystems" are to be protected and enhanced. One strategy to meet the WFD requirements for water bodies, therefore, is to maximise the nutrient removal and reduction abilities of some wetlands. Where those wetlands are adjacent to, or continuous with, a water body covered by the WFD, the directive should provide for protection.

\section{References}

Allinson, G., Stagnitti, F., Salzman, S., Hill, R.J., Coates, M., Cordell, S., Colville, S. and Lloyd-Smith, J., 2000. Strategies for the sustainable management of industrial wastewater. Determination of the chemical dynamics of a cascade series of five newly constructed ponds. Phys. Chem. Earth (B), 25, 629634.

Ambus, P. and Christensen, S., 1993. Denitrification variability and control in a riparian fen irrigated with agricultural drainage water. Soil Biol. Biochem, 25, 915-923.

Armstrong, W., 1964. Oxygen diffusion from the roots of British bog plants. Nature, 204, 801-802.

Baker, C.J. and Maltby, E., 1995. Nitrate removal by river marginal wetlands: factors affecting the provision of a suitable denitrification environment. In: Hydrology and Hydrochemistry of British Wetlands, J.Hughes and L.Heathwaite (Eds.) Wiley, Chichester, UK. 291-313.

Barko, J.W. and Smart, R.M., 1980. Mobilisation of sediment phosphorus by submersed freshwater macrophytes. Freshwater Biol., 10, 229-238.

Bowden, W.B., 1987. The biogeochemistry of nitrogen in freshwaters. Biogeochem., 4, 313-348.

Boyt, F.L., 1977. Removal of nutrients from treated municipal wastewater by wetland vegetation. J. Water Pollut. Control Fed., 49, 789.

Bratli, J.L., Skiple, A. and Mjelde, M., 1999. Restoration of lake Borrevannet - Self-purification of nutrients and suspended matter through natural reed-belts. Water Sci. Technol., 40, 325332.

Brinson, M.M., Bradshaw, H.D. and Kane, E.S., 1984. Nutrient assimilative capacity of an alluvial floodplain swamp. J. Appl. Ecol., 21, 1041-1057.

Broadbent, F.E. and Clark, F.E., 1965. Soil nitrogen., W.V. Bartholomew and F.E.Clark (Eds.). Agron. 10, 344.

Brunet, R.C., Pinay, G., Gazelle, F. and Roques, L., 1994. Role of the floodplain and riparian zone in suspended matter and nitrogen retention in the Adour River, south-west France. Regul. River., 9, 55-63. 
Bugenyi, F.W.B., 1993. Some considerations on the functioning of tropical riparian ecotones. Hydrobiologia, 251, 33-38.

Bullock, A. and Acreman, M., 2003. The role of wetlands in the hydrological cycle. Hydrol., Earth Syst .Sci., 7, 358-389.

Burke, W., 1975. Fertilizer and other chemical losses in drainage water from a blanket bog. Irish J. Agr. Res., 14, 163-168

Burt, T.P., Matchett, L.S. and Haycock, N.E., 1998. Floodplain as buffer zones. In: United Kingdom Floodplains. Westbury Publishing, . Otley, West Yorkshire, UK.

Carpenter, S.R., 1980. Enrichment of Lake Wingra, Wisconsin, by submersed macrophyte decay. Ecology, 61, 1145-1155.

CEC, 1995. Wise use and conservation of wetlands. Communication from the Commission to the Council and the European Parliament, Commission of the European Communities COM (95) 189(final), 54pp.

Chague-Goff, C., Rosen M.R. and Eser, P., 1999. Sewage effluent discharge and geothermal input in a natural wetland, Tongaririo Delta, New Zealand. Ecol. Eng., 12, 149-170.

Chauvelon, P., 1998. A wetland managed for agriculture as an interface between the Rhone river and the Vaccares lagoon (Camargue, France): transfers of water and nutrients. Hydrobiologia, 373/374, 181-191.

Chescheir, G.M., Gilliam, J.W., Skaggs, R.W. and Broadhead, R.G., 1991. Nutrient and sediment removal in forested wetlands receiving pumped agricultural drainage water. Wetlands, 11, 87103

Clausen, J.C., Wayland, K.G., Saldi, K.A. and Guillard, K., 1993. Movement of nitrogen through an agricultural riparian zone: 1 Field Studies. Water Sci. Technol., 28, 3-5.

Cooke, J.G., 1994. Nutrient transformations in a natural wetland receiving sewage effluent and the implications for waste treatment. Water Sci. Technol., 29, 209-217.

Cooper, A.B., 1990. Nitrate depletion in the riparian zone and stream channel of a small headwater catchment. Hydrobiologia, 202, 13-26.

Cooper, A.B., 1994. Coupling wetland treatment to land treatment: an innovative method for nitrogen stripping. Water Sci. Technol., 29, 141-149.

Cooper, A.B. and Gilliam, J.W., 1987. Phosphorus redistribution from cultivated fields into riparian areas. Soil Sci. Soc.Amer.J., 51, 1600-1604.

Craft C.B. and Casey, W.P., 2000. Sediment and nutrient accumulation in floodplain and depressional freshwater wetlands of Georgia, USA. Wetlands, 20, 323-332.

Daniels, R.B. and Gilliam, J.W., 1996. Sediment and chemical load reduction by grass and riparian filters. Soil Sci. Soc. Amer. J., 60, 246-251.

Dillaha, T.A., Sherrard, J.H., Lee, D., Mostaghimi, S. and Shanholtz, V.O., 1988. Evolution of vegetative filter strips as a best management practice for feed lots. J. Water Pollut. Cont. Fed., 60, 1231-1238.

Dorge, J., 1994. Modelling nitrogen transformations in freshwater wetlands. Estimating nitrogen retention and removal in natural wetlands in relation to their hydrology and nutrient loadings. Ecol. Model., 75/76, 409-420.

Downes, M.T.,1997. Long and short roads to riparian restoration: nitrate removal efficiency. In: Buffer Zones. Environment Agency, UK. 244-254

Dugan, P.J., 1990. Wetland Conservation: a review of current issues and required action. IUCN, Gland, Switzerland, $96 \mathrm{pp}$.

Elder, J.F., 1985. Nitrogen and phosphorus speciation and flux in a large Florida river wetland system. Water Resour. Res., 21, 724-732.
Fleischer, S., Joelsson, A. and Stibe, L., 1997. The potential role of ponds as buffer zones. In: Buffer Zones: their processes and potential in water protection, N.E. Haycock, T.P.Burt, K.W.T. Goulding and G.Pinay (Eds.) Quest Environmental, Harpenden, UK.

Gehrels, J. and Mulamootth, G., 1989. The transformation and export of phosphorus from wetlands. Hydrol. Process., 3, 365370.

Hammer, D.A., 1992. Designing constructed wetland systems to treat agricultural non-point source pollution. Ecol. Eng., 1, 4982.

Hanson, G.C., Groffman, P.M. and Gold, A.J., 1994. Denitrification in riparian wetlands receiving high and low groundwater nitrate inputs. J. Environ. Qual., 23, 917-922.

Haycock, N.E. and Burt, T.P., 1993. Role of floodplain sediments in reducing the nitrate concentration of subsurface run-off: a case study in the Cotswolds, UK. Hydrol. Process., 7, 287295.

Haycock, N.E. and Pinay, G., 1993. Groundwater nitrate dynamics in grass and poplar vegetated riparian buffer strips during the winter. J. Environ. Qual., 22, 273-278.

Haycock, N.E., Pinay, G. Burt, T.P., and Goulding, KW.T., 1997. Buffer Zones: current concerns and future directions. In: Buffer Zones: their processes and potential in water protection, N.E Haycock, T.P. Burt, K.W.T Goulding and G. Pinay (Eds.) Quest Environmental, Harpenden, UK.

Hench, K.R., Bissonnette, G.K., Sexstone, A.J., Coleman, J.G., Garbutt, K. and Skousen, J.G., 2003. Fate of physical, chemical and microbial contaminants in domestic wastewater following treatment by small constructed wetlands. Water Res., 37, 921927.

Hill, A.R., 1997. The potential role of in-stream and hyporheic environments as buffer zones.In: Buffer Zones: their processes and potential in water protection, N.E Haycock, T.P.Burt, K.W.T Goulding and G, Pinay (Eds.) Quest Environmental, Harpenden, UK.

Hill, A.R. and Sanmugadas, K., 1985. Denitrification rates in relation to stream characteristics. Water Res., 19, 1579-1586.

Hill, A.R. and Shakleton, M., 1989. Soil N mineralization and nitrification in relation to nitrogen solution chemistry in a small forested watershed. Biogeochemistry, 8, 167-184.

Hogan, D.V., Maltby, E., Lloyd, J.W. and Baker, C.J., 1992. Water resource management and the protection of wetland functioning. NRA: Research and Development Priorities. : NRA Wessex Region.

Horne, A.J., 1971. Laboratory and in-situ studies of the phytoplankton blooms in eutrophic Clear Lake, California. Brit. Phycol. J. 6, 270.

Hurd, T.M., Rynal, D.J. and Schwintzer, C.R., 2001. Symbiotic nitrogen fixation of Alnus incana spp rogosa in shrub wetlands of the Adirondack Mountains, New York, USA. Oecologia, 126, 94-103.

Jacobs, T.C. and Gilliam, J.W., 1985. Riparian losses of nitrate from agricultural drainage waters. J. Environ. Qual., 14, 472478.

James, C., Fisher, J. and Moss, B., 2003. Nitrogen-driven lakes: The Shropshire and Cheshire Meres. Arch. Hydrobiol., 158, 249266.

Jensen, H.S, Kristensen, P., Jeppensen, E. and Skytth, A., 1992. Iron:phosphorus ratio is surface sediments as an indicator of phosphorus release from aerobic sediments in shallow lakes. Hydrobiologia, 235/236, 731-743.

Johnston, C.A., Bubenzer, G.D., Lee, G.B., Madison, F.W. and McHenry, J.R., 1984. Nutrient trapping by sediment deposition in a seasonally flooded lakeside wetland. J. Environ. Qual., 13, 283-290. 
Jordan, T.E., Correll, D.L. and Weller, D.E., 1993. Nutrient interception by a riparian forest receiving inputs from adjacent cropland. J. Environ. Qual., 22, 467-473.

Jordan T.E., Whigham D.F., Hofmockel, K.H. and Pittek, M.A., 2003. Nutrient and sediment removal by a restored wetland receiving agricultural runoff. J. Environ. Qual., 32, 1534-1547.

Kadlec, R.H., 1985. Aging phenomena in wastewater wetlands. In: Ecological Considerations in Wetlands Treatment of Municipal Wastewaters, P.J.Godfrey, E.R., Kaynor, S.Pelczarski and J.Benforado (Eds.), Van Nostrand Reinhold, New York, USA.

Kansiime, F. and Nalubega, M.,1999. Waste Water Treatment by A Natural Wetland:The Nakivubo Swamp, Uganda, Processes and Implications. PhD Thesis, UNESCO-IHE Institute for Water Education, Delft, The Netherlands.

Karr, J.R. and Schlosser, I.J., 1978. Water resources and the landwater interface. Science, 201, 229-234.

Kellogg, L.E. and Bridgham, S.D., 2003. Phosphorus retention and movement across an ombrotrophic-minerotrophic peatland gradient. Biogeochemistry, 63, 299-315.

Khalid, R.A., Patrick, W.H. and DeLaune R.D., 1977. Phosphorus sorption characteristics of flooded soils. Soil Sci. Soc. Amer. J., 41, 305-310.

Koch, M.S., Maltby, E., Oliver, G.A. and Bakker, S., 1992. Factors controlling denitrification rates of tidal mudflats and fringing salt marshes in S/W England. Estuar. Coast. Shelf Sci., 34, 471-485.

Lee, G., Bentley, E. and Amundson, R., 1975. Effects of marshes on water quality. In: Coupling of Land and Water Systems, A. Hasler (Ed.), Springer, New York, USA.

Lindkvist, H., 1992. Fosfor-och partickelfangande egenskaper hos en hallandsk damm under ett hostflode. Swedish University of Agricultural Sciences, Division of Water Management, Uppsala, Sweden.

Lindkvist, H. and Hakånsson, Å., 1993. Kvave-, fosfor-och partickelfangande egenskaper hos en hallandsk damm under ett varflode. Swedish University of Agricultural Sciences, Division of Water Management, Uppsala, Sweden.

Lowrance, R.R., Todd, R.L.and Asmussen, L.E., 1984. Nutrient cycling in an agricultural watershed: II Streamflow and artificial drainage. J. Environ. Qual., 13, 27-32.

Machefact, S.E., Dise, N.B., Goulding, K.W.T. and Whitehead, P.G., 2002. Nitrous oxide emission from a range of land uses across Europe. Hydrol. Earth Syst. Sci., 6, 325-337.

Maltby, E., 1990 Waterlogged Wealth - Why waste the world's wet places? Earthscan. London, UK

Maltby, E., Hogan, D.V. and Oliver, G.A., 1995. Wetland soil hydrological and ecosystem functioning. In: Hydrology and Hydrochemistry of British Wetlands, J.M.R. Hughes. and A.L. Heathwaite (Eds.), Wiley Chicester, UK. 325-362.

Mander, U., Matt, O. and Nugin, U., 1991. Persectives on vegetated shoals, ponds and ditches as extensive outdorr systems of wastewater treatment in Estonia. In: Ecological Engineering for Wastewater Treatment, C.Ethier and B.Guterstam, (Eds.). Proceedings of the International Conference at Stensund Folk College, Sweden.

Mander, U., Lomus, K., Kuusemets, V. and Ivask, M., 1997. The potential role of wet meadows and grey alder forests as buffer zones.In: Buffer Zones: their processes and potential in water protection,. N.E Haycock, T.P.Burt, K.W.T Goulding and G, Pinay (Eds.) Quest Environmental, Harpenden, UK.

Merritt, A., 1994. Wetlands, Industry and Wildlife - A Manual of Principles and Practices. The Wildfowl and Wetlands Trust, Newcastle upon Tyne, UK.
Mitch, W.J.and Gosselink, J.G., 1986. Wetlands. Van Nostrand Reinhold New York, USA.

Mitchell, D.S., 1994. Floodplain wetlands of the Murray-Darling Basin: management, issues and challenges.In: Murray-Darling Basin floodplain wetlands management, T: Sharley and C.Huggin (Eds.) Proc. of the floodplain wetlands management workshop, NSW, Australia, 1992.

Mortimer, C., 1941. The exchange of dissolved substances between mud and water in lakes. J. Ecol., 30, 147-201.

Mwanuzi, F., Aalderink, H. and Mdamo, L., 2003. Simulation of pollution buffering capacity of wetlands fringing the Lake Victoria. Environ. Int., 29, 95-103.

Nichols, D.S., 1983. Capacity of natural wetlands to remove nutrients from wastewater. J. Water Pollu. Cont. Fed.., 55, 495505.

Nunez Delgado, A., Lopez Periago, E., Diaz-Fierros, F., 1997. Effectivness of buffer strips for attenuation of ammonium and nitrate levels in runoff from pasture amended with cattle slurry of inorganic fertilizer. In: Buffer Zones: their processes and potential in water protection. N.E.Haycock, T.P.Burt, K.W.T. Goulding and G.Pinay. (Eds.) Quest Environmental, Harpenden, UK.

Omernik, J.M; Abenathy, A.R. and Male, L.M., 1981. Stream nutrient levels and proximity of agricultural and farm land to streams: some relationships. J. Soil Water Conserv., 36, 227231

Ontkean G.R., Chanasyk D.S., Riemersma, S., Bennett, D.R. and Brunen, J.M., 2003. Enhanced prairie wetland effects on surface water quality in Crowfoot Creek, Alberta. Water Qual. Res. J. Canada, 38, 335-359.

Osborne, P.L. and Totome, R.G., 1994. Long-term impacts of sewage effluent disposal on a tropical wetland. Water Sci. Techol., 29, 111-117.

Patrick, W.H. Jr. and Wyatt, R., 1964. Soil nitrogen loss as a result of alternate submergence and drying. Soil Sci. Soc. Amer. Proc., 28, 647-653.

Patruno, J. and Russell, J., 1994. Natural wetland polishing effluent discharging to Wooloweyah Lagoon. Water Sci. Technol., 29, 185-192.

Peterjohn, W.T. and Correll, D.L., 1984. Nutrient dynamics in an agricultural watershed: Observations on the role of a riparian forest. Ecol., 65, 1466-1475.

Pinay, G. and Decamps, H., 1988. The role of riparian woods in regulating nitrogen fluxes between the alluvial aquifer and surface water: a conceptual model. Regul. River., 2, 507-516.

Prior, H., 1998. Total nitrogen and total phosphorus cycling in riparian ecosystems. PhD Thesis, University of Reading, Whiteknights, Reading, UK.

Raisin, G.W. and Mitchell, D.S., 1995. The use of wetlands for the control of non-point source pollution. Water Sci. Technol., 32, 177-186.

Richardson, C.J., 1985. Mechanisms controlling phosphorus retention capacity in freshwater wetlands. Science, 228, 14241427.

Ross, S.M., 1995. Overview of the hydrochemistry and solute processes in British Wetlands. In: Hydrology and Hydrochemistry of British Wetlands. J.M.R Hughes and A.L, Heathwaite (Eds.), Wiley, Chichester, UK.

Rzepecki, M., 2002. Wetland zones along shores as barrier systems: field and experimental research on nutrient retention and dynamics. Polish J. Ecol., 50, 527-541.

Schindler, D.W., 1977. Evolution of phosphorus limitation in lakes. Science, 195, 260-262.

Schlosser, I.J. and Karr, J.R., 1981. Water quality in agricultural watersheds: Impact of riparian vegetation during baseflow. Water Res. Bull., 17, 233-240. 
Schwer, C.B. and Clausen, J.C., 1989. Vegetation filter treatment of diary milk house wastewater. J. Environ. Qual., 18, 446451.

Semkin, R.G., 1976. A water quality study of Cootes Paradise. Ontario Ministry of the Environment, West Central Region, Toronto, Ontario, Canada..

Shutes, R.B.E., 2001. Artificial wetlands and water quality improvement. Environ. Int., 26, 441-447.

Spangler, F.L., C.W. Fetter and W.E. Sloey., 1977. Phosphorus accumulation-discharge cycles in marshes. Water Res. Bull., 13, 1191

Stephen, D., Moss, B. and Phillips, G., 1997. Do rooted macrophytes increase sediment phosphorus release? Hydrobiologia, 342, 27-34.

Tilton, D.L. and Kadlec, R.H., 1979. The utlization of a freshwater wetland for nutrient removal from secondary treated waste water effluent. J. Environ. Qual., 8. 328.
Uusi-Kamppa, J, Turtola, E. and Ylaranta, T., 1997. The interactions of buffer zones and phosphorus runoff. In: Buffer Zones: Their processes and potential in Water Protection, N.E. Haycock, T.P. Burt, K.W.T. Goulding and G. Pinay. (Eds.) Quest Environmental, Harpenden, UK.

Vanek, V., 1991. Riparian zone as a source of phosphorus for a groundwater dominated lake. Water Res., 25, 409-418.

Wetzel, R.G., 2001. Fundamental processes within natural and constructed wetland ecosystems: short-term versus long-term objectives. Water Sci. Technol., 44, 1-8.

Yonika, D. and Lowry, D., 1979. Feasibility study of wetland disposal of wastewater treatment plant effluent. Final Report to the Mass. Water Resources Commission, Mass., USA

Zhang, X.W., Feagley, S.E., Day J.W., Conner W.H., Hesse, I.D., Rybczyk, J.M. and Hudnall, W.H., 2000. A water chemistry assessment of wastewater remediation in a natural swamp. $J$. Environ. Oual., 29, 1960-1968. 